\title{
Human Capital Integration Model With Technology Innovation In Small And Medium Enterprises (SME)
}

\author{
Mudji Astuti \\ Prodi Manajemen, FakultasEkonomi \\ UniversitasMuhammadiyahSidoarjo \\ Sidoarjo, Indonesia \\ Mudji.astuti@ymail.com
}

\author{
Hana Catur Wahyuni \\ Prodi TeknikIndustri, FakultasTeknik \\ UniversitasMuhammadiyahSidoarjo \\ Sidoarjo, Indonesia \\ hanacatur@umsida.ac.id
}

\begin{abstract}
Environmental management in the business operational process (MSMEs), give a positive influence on MSMEs sustainability in the short and long term. Green human resource management (Green HRM) is one tool that can be used to manage MSMEs workforce by involving environmental aspect.This study aims to determine the model of integration between human capital and technological innovation in MSMEs. The research variables used consist of human capital, technological innovation and productivity. The study was conducted on manufacturing MSMEs located in East Java. Data processing is done by using discrete statistic. The results show that the integration between human capital can be done through the stages of labor development as a human capital in MSMEs, then can be done technological innovation. The competencies expected in human capital of MSMEs are Visionary, Business managerial ability, Ability to formulate business strategy, Open with renewal, Soul of good leadership, Communicative (able to negotiate with external party).
\end{abstract}

Keywords—human capital; technology innovation; productivity; SME; integration

\section{INTRODUCTION}

Micro, Small and Medium Enterprises (MSMEs) are economic mobilizers and have contributed enormously to the stability of the economy in Indonesia. MSMEs have proved robust in facing the economic crisis because it has a high flexibility and elasticity and even showed a very rapid growth [1]. Basically, the development of MSMEs characterized by increased productivity depends on the ability of innovation owned by labor and technology companies [2]. The results of research conducted by the authors of 2013 showed that there is a positive relationship between technological innovation with UMKM productivity [3]. The results also indicate a positive relationship between labor and UMKM productivity but the role of labor on improving UMKM productivity is still low [3]. Moreover, MSMEs have constraints related to technology, limited access to market information, limited market, network, and strategic business location access, procurement of raw materials with low price and good quality, and labor skills $[4,5]$.

UMKM conditions in East Java in general still using simple technology, modern processing technology has not been much mastered. In fact, to be able to increase productivity in order to have competitiveness in the global market, the SMEs should make technological innovations in the production process. In addition, the obstacles to the use of technology to improve the productivity of MSMEs are also due to technological discrepancies in terms of capacity, quality, and sustainability so that the results obtained are not as expected, often to result in inefficiencies, low quality and product competitiveness [6,7].

The description shows that labor and technological innovation have an important role in the development of MSMEs. Therefore, at present, labor is viewed as an organizational capital, called human capital (HC). The advantages of $\mathrm{HC}$ compared to other factors of production of the competition strategy of an organization include: the ability of innovation and entrepreneurship, unique qualities, special skills, ability to provide different services and productivity capabilities that can be developed as needed. Meanwhile, technological innovation is an important factor of economic growth, increasing product competitiveness in the face of globalization era $[8,9]$. In addition, technological innovation can be used as a tool to expand product markets, improve organizational performance to be more efficient, introduce products or processes.

The existence of a gap between the importance of the role of $\mathrm{HC}$ and technological innovation to improve productivity and product competitiveness with real conditions of SMEs is a problem that must be addressed. Considering, the role of technological innovation is crucial to improving SMEs productivity through time savings, cost effectiveness improvement, better presentation, information sharing, improving workers skills, improving corporate communications with external parties, and improving access to trade information. Therefore we need a development of human capital integration model and technological innovation to improve the quality and competitiveness of SMEs products. This study aims to determine the model of integration between human capital and technological innovation in SMEs.

\section{RESEARCH METHODOLOGY}

The research object used is manufacturing SMEs in East Java. The data were collected by distributing questionnaires, 
using the respondents' scores using 4 likert scales: 1: not important (NI), 2: important enough (NE), 3: important (I) and 4: very important (VI). Data processing is done by using descriptive statistics. This research uses human capital variable, technological innovation, productivity and product competitiveness in describing the integration model. Each variable is equipped with the following indicators:

TABLE I. INDICATOR RESEARCH

\begin{tabular}{|c|c|c|c|}
\hline Latent Variable & \multicolumn{2}{|r|}{ Indicator } & Reference \\
\hline \multirow{4}{*}{ Human Capital (HC) } & P1.1 & Individual capability & \multirow{4}{*}{ [10] } \\
\hline & P1.2 & Individual motivation & \\
\hline & P1.3 & Leadership & \\
\hline & P1.4 & The organizational climate & \\
\hline \multirow{4}{*}{$\begin{array}{l}\text { Technology } \\
\text { Innovation }\end{array}$} & P2.1 & Innovation planning & \multirow{4}{*}{ [11] } \\
\hline & P2.2 & Innovation imlpementation & \\
\hline & P2.3 & Innovation platform & \\
\hline & P2.4 & Innovation performance & \\
\hline \multirow{4}{*}{ SMEs Productivity } & P3.1 & Capital & \multirow{4}{*}{ [3] } \\
\hline & P3.2 & Labor & \\
\hline & P3.3 & Energy & \\
\hline & P3.4 & Raw material & \\
\hline
\end{tabular}

\section{RESULT AND DISCUSSION}

The number of samples used was 94 samples distributed over the four districts. The amount is in accordance with the provisions mentioned in research methodology, namely: $5 \mathrm{x}$ the number of variables $=5 \times 14=70$ samples. Therefore, the numbers of samples distributed as many as 94 questionnaires $\geq 70$ samples, then the data is said enough, and can be used for the next process. Furthermore, the questionnaire results are tested for reliability and validity test using 16 series spss. Reliability tests results and validity indicate that the questionnaire is reliable and valid, so it can proceed with the next process.

Data processing is done by using descriptive statistic, that is grouping of questionnaire result based on its variable. Results of data processing show as follows:

\section{A. Human Capital Variable}

TABLE II. THE RESULTS OF RESPONDENTS' ASSESSMENT OF HUMAN CAPITAL VARIABLES

\begin{tabular}{|l|c|c|c|c|c|}
\hline \multirow{2}{*}{ Indicator } & \multicolumn{4}{|c|}{ Result of respondent } & \multirow{2}{*}{ Total } \\
\cline { 2 - 6 } & NI & IE & I & VI & 94 \\
\hline $\begin{array}{l}\text { Individual } \\
\text { capability }\end{array}$ & 4 & 24 & 30 & 36 & 94 \\
\hline $\begin{array}{l}\text { Organizational } \\
\text { climate }\end{array}$ & 10 & 30 & 42 & 12 & 94 \\
\hline $\begin{array}{l}\text { Individual } \\
\text { motivation }\end{array}$ & 4 & 22 & 48 & 20 & 94 \\
\hline Leadhership & & 24 & 44 & 26 & 94 \\
\hline
\end{tabular}

Based on table II, it is seen that most of the respondents rate it very important for individual capability indicators, since most respondents rate it important for other organizational climate, individual motivation and leadhership.

\section{B. Technology Innovation}

TABLE III. RESULTS OF RESPONDENTS' ASSESSMENT OF TECHNOLOGICAL INNOVATION VARIABLES

\begin{tabular}{|c|c|c|c|c|c|}
\hline \multirow{2}{*}{ Indicator } & \multicolumn{4}{|c|}{ Result of respondent } & \multirow{2}{*}{ Total } \\
\hline & NI & IE & I & VI & \\
\hline Innovation planning & 6 & 30 & 30 & 28 & 94 \\
\hline $\begin{array}{l}\text { Innovation } \\
\text { imlpementation }\end{array}$ & & 42 & 44 & 8 & 94 \\
\hline Innovation platform & 4 & 44 & 40 & 5 & 94 \\
\hline $\begin{array}{l}\text { Innovation } \\
\text { performance }\end{array}$ & & 44 & 38 & 12 & 94 \\
\hline
\end{tabular}

Based on table III it is seen that most respondents considered it important to innovation planning indicators and innovation implementation, while innovation platform indicators and innovation performance are considered important.

C. Productivity

TABLE IV. RESULTS OF RESPONDENTS' ASSESSMENT OF PRODUCTIVITY VARIABLES

\begin{tabular}{|c|c|c|c|c|c|}
\hline \multirow{2}{*}{ Indicator } & \multicolumn{4}{|c|}{ Result of respondent } & \multirow{2}{*}{ Total } \\
\hline & NI & IE & $\mathbf{I}$ & VI & \\
\hline Capital & 2 & 18 & 24 & 50 & 94 \\
\hline Labor & 6 & 12 & 40 & 36 & 94 \\
\hline Energy & 8 & 14 & 46 & 26 & 94 \\
\hline Raw material & & 10 & 34 & 50 & 94 \\
\hline
\end{tabular}

Table IV shows the results of respondents' assessment of the productivity variables. The results of the assessment indicate that capital and raw materials are very important productivity indicators, while energy and labor indica- tors are considered important by the respondents.

Results of field observations indicate that labor conditions as human capital received less serious attention to owners of MSMEs or stakeholders (Government). Observation results to indicate that the current workforce functions as an operator in charge of running all the mechanisms of the production process, but has not received self-development treatment for the form of training or opportunities for self-development. Most of the attention to SMEs owners to the workers in the form of material, such as salary, bonuses in the form of money or goods etc. Therefore, the integration models on human capital, technological innovation and productivity is formulated as follows:

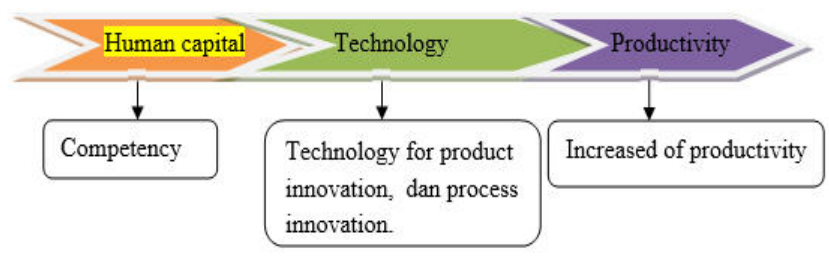

Fig. 1. Human Capital Integration Model with Technology Innovation Some Common Mistakes 
The model of human capital integration with technological innovation shows that human capital which in implementation in UMKM in the form of labor is the basic factor of technological innovation. Furthermore, technological innovations conducted by SMEs lead to increased productivity.

\section{CONCLUSION}

Integration between human capital can be done through the stages of labor development as a human capital in MSMEs, then can be done technological innovation. The expected competencies in human capital of UMKM are Visionary, Business managerial ability, Ability to formulate business strategy, Open with renewal, Good leadership spirit, Communicative (able to negotiate with external party)

\section{REFERENCES}

[1] Hamid, 2010, Pengembangan UMKM Untuk Meningkatkan Pertumbuhan Ekonomi Daerah, Simposium Nasional: Menuju Purworejo Dinamis dan Kreatif, Yogyakarta.

[2] Tastan.S.C., 2013, The Influence Of Participate Organizational Climate And Self Leadership On Innovative Behavior And The Role Of Job Involvement And Proactive Personality: A Survey In Context Of SMEs In Izmir, ProcediaSosial And Behavior Sciences 75, pp 407-419.

[3] Astuti M, Wahyuni H.,C, Sulistiyowati W.,Ciptomulyono U., Kartiningsih P.D., 2013, Peningkatan Produktivitas Usaha Kecil dan
Menengah (UKM) berbasis Technology Content Untuk Mendukung Pelaksanaan MP3EI 2011-2025, Proceding Seminar Nasional Fakultas Ekonomi, Universitas Muhammadiyah Sidoarjo, Juni, ISBN: 978-60298739-1-7.

[4] Fitanto, 2009, Analisis Omzet dan Posisi Bersaing Pada Kluster Usaha Kecil dan Menengah (UKM) Sepatu Kota Mojokerto, Journal Of Indonesian Applied Economics, Vol 3 No 1,hal 23-36, Mei.

[5] Irjayanti M.,Azis AM., 2012, Barrier Factors and Potential Solutions For Indonesia SMEs, Procedia Economic and Finance 4, pp 3-12.

[6] Marshal R, 2012, Penerapan Energi Efisiensi di IKM, Workshop Efisiensi Energi Di Sektor Industri Kecil Dan Menengah, 27 Maret, Jakarta.

[7] Mizar, Mawardi M., Maksum, Raharjo, 2008, Tipologi dan Karakteristik Adopsi Teknologi Pada Industri Kecil Penggolah Hasil Petanian, Proceding Seminar Nasional Teknik Pertanian, 18-19 Nopember, Yogyakarta.

[8] Youli X., Huiwei L, 2011, Research On Evaluation Of Enterprises'Technology Innovation Performance From The Perspective Of Industrial Cluster Network, Energy Procedia 5, pp 1279-1283.

[9] Minghua L., Yongzhong Y, 2011, Enviromental Regulation And Technology Innovation Evidence From China, Energy Procedia 5, pp 572-576.

[10] Ongkoraharjo, Susanto A, Rachmawati D, 2008, AnalisisPengaruh Human Capital Terhadap Kinerja Perusahaan (Studi Empiris Pada Kantor Akuntan Publik Di Indonesia), Jurnal Akuntansi dan Keuangan, Vol 10 No 1, Mei, hal 11-21.

[11] Liu M., Li M.,Zang T, 2012, Empirical Research On China SMEs Technology Innovation Enggineering Strategy, System Engineering Procedia 5, pp 372-378. 